\title{
Platinum-Catalyzed Reductive Aldol and Michael Reactions
}

\author{
Harim Lee, Min-Soo Jang, Young-Jin Song, and Hye-Young Jang \\ Division of Energv Srstems Research, Ajou Chiversity. Suwon 4+3-749, Korea. E-mail hyangâajouackr \\ Received November 18, 2008, Accepted December 9, 2008

\begin{abstract}
For the Pt-catalyzed nucleophilic addition of enones, Pt complexes were employed in the presence of various phosphine ligands and $\mathrm{H}_{2}$ (or $\mathrm{Et}_{3} \mathrm{SiH}$ ), affording inter- and intra-molecular coupling products in good to modest yield. Depending on reaction protocols, different phosphine ligands were required to optimize the conditions. In the aldol reaction, the $\mathrm{Pt}$ cataly st involving $\mathrm{P}\left(2,4,6-(\mathrm{OMe})_{3} \mathrm{C}_{6} \mathrm{H}_{2}\right)_{3}$ or $\mathrm{P}\left(p-\mathrm{OMeC} \mathrm{M}_{4}\right)_{3}$ was chosen. Michael reaction proceeds in good yields in the presence of $\mathrm{P}\left(p-\mathrm{CF}_{3} \mathrm{C}_{0} \mathrm{H}_{4}\right)_{3}$. Regarding the activity of the reductants, $\mathrm{H}_{2}$ exhibited superior activity to $\mathrm{E}_{3} \mathrm{SiH}$, resulting in a shorter reaction time and higher yield in the aldol and Michael reaction. In light of the deuterium labeling studies, the catalytic cycle including the hydrometalation of the enones by the
\end{abstract} \\ platinum hydride species was proposed.
}

Key Words: Platinum chloride. Reductive aldol reaction, Reductive Michael reaction

\section{Introduction}

Platinum complexes have received a great deal of attention as powerful catalysts for the synthesis of a diverse range of molecules including natural building blocks. ${ }^{1}$ Pt-catalyzed coupling protocols can be divided into two categories; 1) the reactions of Pt bound alkenes (alky nes) with nucleophiles and 2) the reactions of Pt bound alkenes (alky'nes) with electrophiles (Scheme 1). In the Pt-catalyzed cycloisomerization of enynes and the hydroalkoxylation (hydroamination) of alkenes, Pt complexes pull the electron density from the $\pi$-bond of alkenes or alkynes upon coordination. As a result the Pt bound alkenes or alky nes become electron-deficient, thereby allowing them to react with nucleophiles. ${ }^{2}$ In contrast, $\mathrm{Pt}$ complexes in the presence of silanes or lydrogen exlibit different reactivity toward the $\pi$-bond. ${ }^{3.4}$ In the Pt-catalyzed lydroformylation of alkenes. Pt complexes react with the $\mathrm{H}_{z}$ and alkenes, affording Ptalkyl complexes. which undergo migratory insertion to carbon monoxide. ${ }^{5}$ Considering the remarkable activity of $\mathrm{Pt}$ complexes toward electron deficient functional groups during the hydroformylation, Pt complexes with suitable reductants are expected to conduct the reductive coupling of alkenes (alkynes) and electron deficient functional groups. Hence, we embarked on a study of reductive coupling reactions utilizing $\mathrm{PtCl}_{2}$ with electronically different phosphine ligands in the presence of reductants.

In the case of $\mathrm{Rh}$. Ir. Pd. and $\mathrm{Ni}$ complexes. the reductive couplings of alkenes and alkynes through their hydrometalation are well known. ${ }^{3}$ In particular activated alkenes (enones) undergo hydrometalation at the alkene of the enone in the presence of transition metal catalysts and reductants. affording hydrometalated products (metal enolates). Transition metal
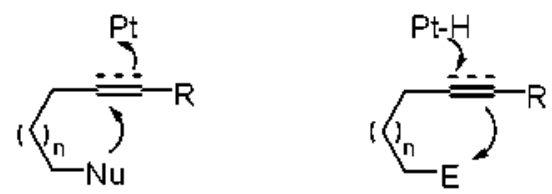

Scheme 1. Pt-catalyzed cyclization enolates participate in the successive addition to activated alkenes (Michael addition), aldehydes (aldol addition). and imines (Mannich reaction). etc. ${ }^{\text {s. } 11}$ Among the available reductants, hydrogen and silanes have emerged as pronising ones. since reductive coupling reactions using these reagents provide high selectivity of the products and functional group tolerance. In this sense, the reductive couplings of enones in the presence of hydrogen and silanes constitute one of the most active areas of transition metal catalysis. ${ }^{16,11}$

With the aim of developing platinum catalyzed protocols for the reductive coupling of enones with electropliles (aldehy'des and enones). we explored various platinum complexes with hydrogen and silanes to obtain the corresponding reductive coupling products. Previously. the Pt-catalyzed hydrogenative Michael cyclization of bis-enones and related mechanistic studies were conducted. ${ }^{12}$ In this account. we discuss Ptcatalyzed intra- and inter-molecular reductive aldol reactions where both hydrogen and the silane are utilized as a hydride source. Deuterium labeling experiments were conducted to confirm the proposed catalytic cycle involving the hydrometalation of the enones and subsequent trapping by the aldelyde. Moreover. the $\mathrm{Pt}$ complexes showing good catalytic activity in the aldol reaction were applied to silane-mediated Michael cyclization of bis-enones.

\section{Results and Discussion}

In an effort to inprove both the diastereoselectivity and reactivity of the catalyst. various phosphine ligands were screened and a low reaction temperature was employed. Table 1 summarizes the results. The reactivity and selectivity of the aldol reaction catalyzed by $\mathrm{PtCl}_{2}$ with $\mathrm{P}\left(p-\mathrm{CF}_{3} \mathrm{C}_{6} \mathrm{H}_{4}\right)_{3}$ and $\mathrm{P}\left(p \text {-OMeC } \mathrm{OH}_{4}\right)_{3}$ were previously reported (Table 1 . entries 1 and 2). ${ }^{12}$ The Pt complex involving the electron-rich phosphine appears to promote the hydrogen-mediated reductive aldol reaction in good yield. $\mathrm{P}(\mathrm{fury \textrm {l }})_{3}$ and 1.2-bis(diphenylphosphino)ethane (dppe) showed diminished yields with poor selectivity (Table 1 , entries 3 and 4 ). The Pt catalyst involving the electron-rich $\mathrm{P}\left(2,4,6-(\mathrm{OMe})_{2} \mathrm{C}_{6} \mathrm{H}_{2}\right)_{3}$ exhibited an increased 
Table 1. Optimization of the reductive aldol reaction<smiles>C=CC(=O)c1ccccc1</smiles>

1a

(200 mol\%)<smiles>O=Cc1ccc([N+](=O)[O-])cc1</smiles>

$1 \mathrm{~b}$

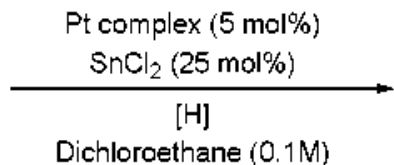

Dichloroethane $(0.1 \mathrm{M})$

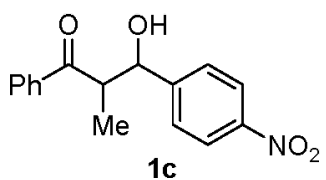

(100 mol\%)

\begin{tabular}{|c|c|c|c|c|c|}
\hline Entry & Pt complext & Ligand & {$[\mathrm{H}]$} & Temp & Yield(sm:anti) \\
\hline 1 & $\mathrm{PtCl}_{2}(5 \mathrm{~mol} \%)$ & $\mathrm{P}\left(p-\mathrm{CF}_{3} \mathrm{C}_{5} \mathrm{H}_{4}\right)_{3}(5 \mathrm{~mol} \%)$ & $\mathrm{H}_{2}(\mathrm{l} \mathrm{atm})$ & $80^{\circ} \mathrm{C}$ & $50 \%(45: 55)$ \\
\hline 2 & $\mathrm{PtCl}_{2}(5 \mathrm{~m} 110 \mathrm{l} \%)$ & $\mathrm{P}\left(p-\mathrm{OMeC}_{n} \mathrm{H}_{4}\right)$ ( $(5 \mathrm{~m} 0 \mathrm{l} \%)$ & $\mathrm{H}_{2}$ (l latm) & $80^{\circ} \mathrm{C}$ & $83 \%(57: 43)$ \\
\hline 3 & $\mathrm{PtCl}_{2}(5 \mathrm{~mol} \%)$ & $\mathrm{P}(\text { turyl })_{3}(5 \mathrm{~mol} \%)$ & $\mathrm{H}_{2}$ (l atm) & $80^{\circ} \mathrm{C}$ & $57 \%(48: 52)$ \\
\hline 4 & $\mathrm{PtCl}_{2}(5 \mathrm{~mol} \%)$ & dppe (5 mol\%) & $\mathrm{H}_{2}$ (l atm) & $80^{\circ} \mathrm{C}$ & $16 \%(58: 42)$ \\
\hline 5 & $\mathrm{PtCl}_{2}(5 \mathrm{~mol} \%)$ & $\mathrm{P}\left(2,4,6-(\mathrm{OMe})_{3} \mathrm{C}_{6} \mathrm{H}_{2}\right)_{3}(5 \mathrm{mnol} \%)$ & $\mathrm{H}_{2}$ (l atm) & $80^{\circ} \mathrm{C}$ & $91 \%(62: 38)$ \\
\hline 6 & $\mathrm{PtCl}_{2}(5 \mathrm{~mol} \%)$ & $\mathrm{P}\left(2,4,6-(\mathrm{OMe})_{3} \mathrm{C}_{6} \mathrm{H}_{2}\right)_{3}(10 \mathrm{~mol} \%)$ & $\mathrm{H}_{2}(\mathrm{l} \mathrm{atm})$ & $80^{\circ} \mathrm{C}$ & $91 \%(84: 16)$ \\
\hline 7 & $\mathrm{PtCl}_{2}(5 \mathrm{~mol} \%)$ & $\mathrm{P}\left(2,4,6-(\mathrm{OMe})_{3} \mathrm{C}_{5} \mathrm{H}_{2}\right)_{3}(5 \mathrm{~mol} \%)$ & $\mathrm{H}_{2}$ (l atm) & $50^{\circ} \mathrm{C}$ & $36 \%(42: 58)$ \\
\hline 8 & $\mathrm{PtCl}_{2}(5 \mathrm{~mol} \%)$ & $\mathrm{P}\left(p-\mathrm{CF}_{3} \mathrm{C}_{6} \mathrm{H}_{4}\right)_{3}(5 \mathrm{~mol} \%)$ & $\mathrm{Et}_{3} \mathrm{SiH}(150 \mathrm{~mol} \%)$ & $50^{\circ} \mathrm{C}$ & $65 \%(74: 26)$ \\
\hline 9 & $\mathrm{PtCl}_{2}(5 \mathrm{~mol} \%)$ & $\mathrm{P}\left(p-\mathrm{OMeC}_{6} \mathrm{H}_{4}\right)_{3}(5 \mathrm{~mol} \%)$ & $\mathrm{Et}_{3} \mathrm{SiH}(150 \mathrm{~mol} \%)$ & $50^{\circ} \mathrm{C}$ & $66 \%(50: 50)$ \\
\hline 10 & $\mathrm{PtCl}_{2}(5 \mathrm{~mol} \%)$ & $P($ furyl $): 5 \mathrm{~mol} \%)$ & $\mathrm{Et}_{3} \mathrm{SiH}(150 \mathrm{~mol} \%)$ & $50^{\circ} \mathrm{C}$ & $64 \%(73: 27)$ \\
\hline 11 & $\mathrm{PtCl}_{2}(5 \mathrm{~m}, 1 \% \mathrm{l} \%)$ & $\mathrm{P}\left(2,4,6-(\mathrm{OMe})_{3} \mathrm{C}_{6} \mathrm{H}_{2}\right)_{5}(5 \mathrm{~m} 1 \mathrm{0l} \%)$ & $\mathrm{Et}_{3} \mathrm{SiH}(150 \mathrm{~mol} \%)$ & $50^{\circ} \mathrm{C}$ & $21 \%(79: 21)$ \\
\hline
\end{tabular}

yield $(91 \%)$ along with improved diastereoselectivity (Table 1. entry 5). Next the amount of $\mathrm{P}\left(2.4 .6-(\mathrm{OMe})_{3} \mathrm{C}_{6} \mathrm{H}_{2}\right)_{3}$ was increased to $10 \mathrm{~mol} \%$ (Table 1 , entry 6). Pleasingly, in this case the ratio of syn to anti products was increased ( $s$ w $:$ anti $=84: 16$ ), while maintaining a similar chemical yield (Table 1 , entry 6). In addition to ligand screening the temperature was lowered to $50^{\circ} \mathrm{C}$. with the expectation that the selectivity of the syn and anti products would be improved. As shown in entry 7 of Table 1 . neither the chemical yield nor the diastereoselectivity was increased. Throughout the optimization procedure. $10 \mathrm{~mol} \%$ of $\mathrm{P}\left(2,4.6-(\mathrm{OMe})_{3} \mathrm{C}_{6} \mathrm{H}_{2}\right)_{3}$ or $10 \mathrm{~mol} \%$ of $\mathrm{P}\left(p-\mathrm{OMeC}_{6} \mathrm{H}_{4}\right)_{3}$ with $5 \mathrm{~mol} \%$ of $\mathrm{PtCl}_{z}$ and $25 \mathrm{~mol} \%$ of $\mathrm{SnCl}_{z}$ was selected as the catalyst of the hydrogenative aldol reaction.

Based on the results of the hydrogenative aldol reaction, $\mathrm{Pt}$ complexes containing $\mathrm{P}\left(p-\mathrm{CF}_{3} \mathrm{C}_{6} \mathrm{H}_{4}\right)_{3} . \mathrm{P}\left(p-\mathrm{OMeC}_{6} \mathrm{H}_{4}\right)_{3}, \mathrm{P}(\text { fury })_{3}$. and $\mathrm{P}\left(2.4 .6-(\mathrm{OMe})_{3} \mathrm{C}_{6} \mathrm{H}_{2}\right)_{3}$ were utilized in the silane-mediated aldol reaction. Since silanes have been utilized in various reductive coupling reactions. Pt complexes with $\mathrm{Et}_{3} \mathrm{SiH}$ would be expected to catalyze the reductive aldol reaction. As indicated in entries $8-10$ of Table 1 . the silane-mediated reductive aldol reactions using $\mathrm{P}\left(p-\mathrm{CF}_{3} \mathrm{C}_{6} \mathrm{H}_{4}\right)_{3}, \mathrm{P}\left(p-\mathrm{OMeC}_{6} \mathrm{H}_{4}\right)_{3}$. and $\mathrm{P}$ (furyl)s provided the products in similar yield $(65 \%$, $66 \%$ and $64 \%$ ). but with different diastereoselectivities. Unlike the hydrogenative aldol reaction enploying $\mathrm{P}\left(2.4,6-(\mathrm{OMe})_{3}\right.$ $\left.\mathrm{C}_{6} \mathrm{H}_{2}\right)_{5}$ diminished the yield of the silane-mediated aldol reaction (Table 1 . entry 11 ). In addition to phosphine ligand screening, a ligher temperature $\left(80^{\circ} \mathrm{C}\right)$ was applied. providing the product in diminished yield. As an optimal catalyst for the silane-mediated reductive aldol reaction, $5 \mathrm{~mol} \%$ of $\mathrm{PtCl}_{2}$ and $25 \mathrm{~mol} \%$ of $\mathrm{SnCl}_{2}$ were applied in the presence of suitable phosphine ligands. Depending on the substrates. different phospline ligands were required to obtain a good yield.

With appropriate sets of reaction conditions, we investigated a range of carbonyl compounds and enones to show the substrate scope of the hydrogen-mediated aldol reactions. The results are shown in Table 2 . Initially. $\beta$-substituted enones were evaluated in the hydrogen-mediated intermolecular reductive aldol reaction (Table 2 , compounds $2 \mathrm{c}$ and

Table 2. The substrate scope of the reductive aldol reaction using $\mathrm{H}_{2}$<smiles>O=C(c1ccccc1)C(Cc1ccccc1)C(O)c1ccc([N+](=O)[O-])cc1</smiles>

2c

$46^{\circ} \circ(\text { sjn:ansi }=55: 45)^{a} \quad 31^{\circ} \circ(\text { syn:anti }=62: 40)^{a}$ $51^{\circ}$ o $(\text { sjon:ansi }=40: 60)^{b} \quad 7500(\text { stn:anti }=15: 85)^{b}$<smiles>CC(C(=O)c1ccccc1)C(O)c1ccc([N+](=O)[O-])o1</smiles>

4c

$990.0(y) n$ anti $=60: 40)$

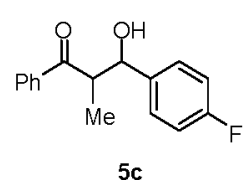

$5 c$

46\% (syn:anti $=75: 25)^{a}$ $71^{\circ}$ o (sin: (anti $\left.=68: 32\right)^{b}$

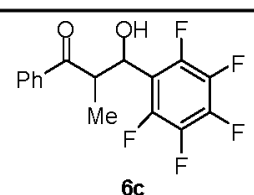

$24 \%(\text { syn:anti }=60: 40)^{a}$ $75^{\circ} \circ$ (siln: anti $=15: 85^{\circ}$<smiles>[M]C(C(=O)c1ccccc1)C(O)c1ccc(Cl)cc1Cl</smiles>

$60^{\circ}$ o (syn:anti $\left.=50: 50\right)^{a}$

$79^{\circ}$ o (syn:tanti $\left.=51: 49\right)^{b}$

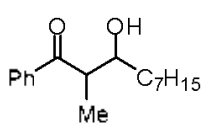

$8 c$

$20^{\circ}$ o $(\text { syn:anti }=83: 17)^{a}$

$94^{\circ}$ o (syn: tunti $\left.=79: 21\right)^{b}$

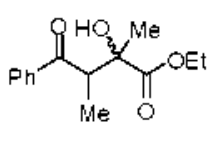

gc

trace $^{a}$

$53^{\circ} \cdot 0^{\circ}$<smiles>O=C(P)C1CCCCC1O</smiles>

$10 \mathrm{c}$

$67^{\circ}{ }^{\circ}$

$58^{\circ} \mathrm{o}^{\mathrm{b}}$ 
Table 3. The substrate scope of the reductive aldol reaction using $\mathrm{Et}_{3} \mathrm{SiH}$<smiles>O=C(c1ccccc1)C(Cc1ccccc1)C(O)c1ccc([N+](=O)[O-])cc1</smiles>

$27^{\circ} \circ(s y n: a n t i=70: 30)^{\prime \prime}$ trace<smiles>CC(C(=O)c1ccccc1)C(O)c1ccc(F)cc1</smiles>

5c

$\operatorname{trace}^{a}$ $\left.48^{\circ} \cdot 1\right)(\text { sy'n:antl }=58: 42)^{b}$

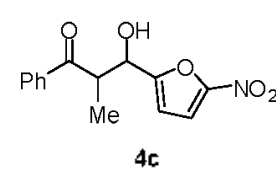

$29^{\circ} \circ(s y n:(m) t i)^{\prime \prime}$ $42^{\circ} \cdot(\sin n: \operatorname{ans} ;=64: 36)^{q}$

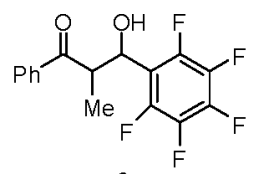

$6 \mathrm{c}$

$72 \%$ (syn:ant $i=5: 95)^{\circ}$ trace<smiles>CC(C(=O)c1ccccc1)C(O)c1ccc(Cl)cc1Cl</smiles>

$7 \mathrm{c}$

$67^{\circ} \circ(\text { stn: } 4 \text { anti }=76: 24)^{4}$

$27^{\circ}$ o $(51 n: a n t i=42: 58)^{b}$<smiles>CCOC(=O)C(C)(O)C(C)C(=O)c1ccccc1</smiles>

sc

$43^{\circ} \mathrm{o}^{\prime \prime}$

$19^{\circ} \mathrm{o}^{\mathrm{b}}$

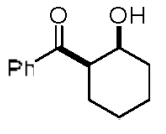

$10 \mathrm{c}$

$60^{\circ} 0^{4}$ $350 \%$
${ }^{a} \mathrm{P}\left(p-\mathrm{OMeC}_{6} \mathrm{H}_{4}\right)_{3}{ }^{k} \mathrm{P}\left(p-\mathrm{CF}_{3} \mathrm{C}_{6} \mathrm{H}_{4}\right)_{3}$

$3 c)$. Upon the exposure of chalcone $2 a$ and nitrobenzaldehyde 1b to the reaction conditions using $\mathrm{P}\left(2.4 .6-(\mathrm{OMe})_{3} \mathrm{C}_{6} \mathrm{H}_{2}\right)_{3}$ and $\mathrm{P}\left(p-\mathrm{OMeC}_{6} \mathrm{H}_{4}\right)_{3}$. $2 \mathrm{e}$ was formed in $46 \%$ and $51 \%$ yields. respectively. indicating that the substituent at the $\beta$-position of the enone strongly retarded the hydrometalation of the enone and the following coupling reaction to $\mathbf{1 b}$. The formation of compound $3 \boldsymbol{c}$ illustrated that the $\beta$-substituted aliphatic enone participated in this reaction to form the desired product in low yield. which might be associated with the steric effect of the octyl group at the $\beta$-position as well as the electronic effect of the methyl group proximal to the carbonyl group. In addition to acyclic enones. the reaction of yclohexenone with $p$-nitrobenzaldehyde $\mathbf{1 b}$ did not provide the coupling product.
A variety of aldehydes were evaluated with phenylvinylketone 1a in the reductive aldol reaction using hydrogen. The heterocyclic aldehyde th participated in this reaction to provide $4 \mathrm{c}$ in $68 \%$ yield in the presence of $\mathrm{P}\left(2,4.6-(\mathrm{OMe})_{\mathbf{s}^{-}}\right.$ $\left.\mathrm{C}_{6} \mathrm{H}_{2}\right)_{3}$. By replacing the phosphine ligands with $\mathrm{P}(p-\mathrm{OMe}-$ $\left.\mathrm{C}_{6} \mathrm{H}_{4}\right)_{3}$, the yield of $4 \mathrm{c}$ was drantatically increased. while the diastereoselectivity was slightly lowered. Aromatic aldehydes possessing electron withdrawing groups exhibit improved yields (5c-7c) under the conditions employing $\mathrm{P}\left(p-\mathrm{OMeC}_{6} \mathrm{H}_{4}\right)_{3}$ rather than $\mathrm{P}\left(2.4,6-(\mathrm{OMe})_{3} \mathrm{C}_{6} \mathrm{H}_{2}\right)_{2}$. Especially. compound $6 \mathrm{c}$ showed significant diastereoselectivity changes in the presence of $\mathrm{P}\left(p-\mathrm{OMeC}_{6} \mathrm{H}_{4}\right)_{z}$. The aliphatic aldehyde octanal $\mathbf{8 b}$ was also coupled to phenylviny lketone 1a to afford $8 \mathrm{c}$ in $94 \%$ yield under the conditions using $\mathrm{P}\left(p-\mathrm{OMeC}_{6} \mathrm{H}_{4}\right)_{3}$. In addition to the aldehyde, the activated ketone. ethyl pyruvate was tested as a carbonyl partner. $\mathrm{P}\left(p-\mathrm{OMeC}_{6} \mathrm{H}_{4}\right)_{3}$ promoted the hydrogenative coupling reaction of ethyl py rusate and phenylvinylketone to afford $9 \mathrm{c}$ as a single diastereoner in good yields. while the Pt catalyst with $\mathrm{P}\left(2.4,6-(\mathrm{OMe})_{3} \mathrm{C}_{6} \mathrm{H}_{2}\right)_{3}$ formed trace amounts of the products. In most intermolecular reactions. under the reaction conditions involving $\mathrm{P}(p-\mathrm{OMe}-$ $\left.\mathrm{C}_{6} \mathrm{H}_{4}\right)_{3}$ rather than $\mathrm{P}\left(2.4,6-(\mathrm{OMe})_{3} \mathrm{C}_{6} \mathrm{H}_{2}\right)_{2}$, higher yields were observed. In the case of $\mathbf{2 c}$ and $\mathbf{6 c}$, remarkable diastereoselectivity changes were detected upon changing the phosphine ligands.

Unlike the intermolecular aldol reaction, the intramolecular aldol reaction proceeds to afford $10 \mathrm{c}$ as a single diastereomer. Presumably. the equilibrium between $E$ and $Z$ forms of the Pt-enolate and the free rotation of the tethered aldehyde might be restricted, providing high selectivity. Both $\mathrm{P}\left(p-\mathrm{OMeC}_{6} \mathrm{H}_{4}\right)_{3}$ and $\mathrm{P}\left(2.4,6-(\mathrm{OMe})_{3} \mathrm{C}_{6} \mathrm{H}_{2}\right)_{3}$ were employed under $\mathrm{l}$ atmosphere of hydrogent. affording $10 \mathrm{c}$ in $67 \%$ and $58 \%$ yields, respectively.

In parallel to the hydrogenative aldol reactions. the silanemediated aldol reactions of various enones and aldehy'des were performed (Table 3). As the catalyst, $5 \mathrm{~mol} \%$ of $\mathrm{PtCl}_{2}$ and $25 \mathrm{~mol} \%$ of $\mathrm{SnCl}_{2}$ were employed in the presence of 5 mol\% of $\mathrm{P}\left(2,4,6-(\mathrm{OMe})_{3} \mathrm{C}_{6} \mathrm{H}_{2}\right)_{3}$ or $\mathrm{P}\left(p-\mathrm{CF}_{3} \mathrm{C}_{6} \mathrm{H}_{4}\right)_{5}$. Upon the exposure of chalcone to the reductive aldol conditions. the

Table 4. Optimization of reductive Michael cyclization<smiles>O=C(/C=C/CCC/C=C/C(=O)c1ccccc1)c1ccccc1</smiles>

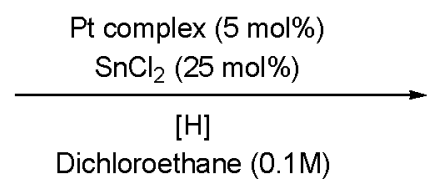<smiles>O=C(CC1CCCCC1C(=O)c1ccccc1)c1ccccc1</smiles>

\begin{tabular}{|c|c|c|c|c|c|}
\hline Entry & Pt complexx & Ligand & {$[\mathrm{H}]$} & Temp & Yield(syn:anti) \\
\hline 1 & $\mathrm{PtCl}_{2}(5 \mathrm{~mol} \%)$ & $\mathrm{P}\left(p-\mathrm{CF}_{3} \mathrm{C}_{6} \mathrm{H}_{4}\right)_{3}(5 \mathrm{~m} 2 \mathrm{0l} \%)$ & $\mathrm{H}_{2}(\mathrm{l}$ atm $)$ & $80^{\circ} \mathrm{C}$ & $69 \%(22: 78)$ \\
\hline 2 & $\mathrm{PtCl}_{2}(5 \mathrm{~mol} \%)$ & $\mathrm{P}\left(p-\mathrm{OMeC}_{n} \mathrm{H}_{4}\right)_{3}(5 \mathrm{~mol} \%)$ & $\mathrm{H}_{2}(\mathrm{l}$ atm $)$ & $80^{\circ} \mathrm{C}$ & $98 \%(33: 67)$ \\
\hline 3 & $\mathrm{PtCl}_{2}(5 \mathrm{~mol} \%)$ & PPh3 $(5 \mathrm{~mol} \%)$ & $\mathrm{H}_{2}(\mathrm{l}$ atm $)$ & $80^{\circ} \mathrm{C}$ & $76 \%(26: 74)$ \\
\hline 4 & $\mathrm{PtCl}_{2}(5 \mathrm{~mol} \%)$ & $\mathrm{P}\left(p-\mathrm{OMeC}_{6} \mathrm{H}_{4}\right)_{3}(5 \mathrm{~mol} \%)$ & $\mathrm{H}_{2}(1 \mathrm{~atm})$ & $80^{\circ} \mathrm{C}$ & $66 \%(28: 72)$ \\
\hline 5 & $\mathrm{PtCl}_{2}(5 \mathrm{~mol} \%)$ & $\mathrm{P}\left(2,4,6-(\mathrm{OMe})_{3} \mathrm{C}_{6} \mathrm{H}_{2}\right)_{3}(5 \mathrm{~m}, 2 \mathrm{ol} \%)$ & $\mathrm{H}_{2}(\mathrm{l}$ atm $)$ & $80^{\circ} \mathrm{C}$ & $79 \%(35: 65)$ \\
\hline 6 & $\mathrm{PtCl}_{2}(5 \mathrm{~mol} \%)$ & $\mathrm{P}(\text { furyl })_{3}(5 \mathrm{~m} 0 \mathrm{l} \%)$ & $\mathrm{H}_{2}$ (l atm) & $80^{\circ} \mathrm{C}$ & $94 \%(38: 62)$ \\
\hline 7 & $\mathrm{PtCl}_{2}(5 \mathrm{~mol} \%)$ & dppe (5 mol\%) & $\mathrm{H}_{2}(\mathrm{l} \operatorname{atm})$ & $80^{\circ} \mathrm{C}$ & NR \\
\hline 8 & $\mathrm{PtCl}_{2}(5 \mathrm{~mol} \%)$ & $\mathrm{P}\left(p-\mathrm{CF}_{3} \mathrm{C}_{5} \mathrm{H}_{4}\right)_{3}(5 \mathrm{~mol} \%)$ & $\mathrm{Et}_{3} \mathrm{SiH}(150 \mathrm{~mol} \%)$ & $50^{\circ} \mathrm{C}$ & $71 \%(29: 71)$ \\
\hline 9 & $\mathrm{PtCl}_{2}(5 \mathrm{~mol} \%)$ & $\mathrm{P}\left(p-\mathrm{CF}_{3} \mathrm{C}_{6} \mathrm{H}_{4}\right):(5 \mathrm{~mol} \%)^{\mathrm{a}}$ & Etş $\mathrm{SiH}(150 \mathrm{~mol} \%)$ & $50^{\circ} \mathrm{C}$ & $24 \%(50: 50)$ \\
\hline 10 & $\mathrm{PtCl}_{2}(5 \mathrm{~mol} \%)$ & $\mathrm{P}\left(p-\mathrm{OMeC}_{6} \mathrm{H}_{4}\right)_{3}(5 \mathrm{~mol} \%)$ & $\mathrm{Et}_{3} \mathrm{SiH}(150 \mathrm{~mol} \%)$ & $50^{\circ} \mathrm{C}$ & $52 \%(25: 75)$ \\
\hline
\end{tabular}


desired product $2 \mathrm{e}$ was formed in $27 \%$ yield. In the case of the nitro-substituted furaldehyde and +-fluorobenzaldehy'de the corresponding aldol products (4c and $\mathbf{5 c}$, repectively) were formed in modest yield. In contrast. multihalogen substituted benzaldehydes required an electron-rich phosphine ligand to obtain a higher yield $(6 \mathrm{c}$ and $7 \mathrm{c}$ ). In addition to the aldehyde, the activated ketone (ethyl py ruvate) reacts with phenylvinylketone to afford $9 \mathrm{c}$ as a single diastereomer. As illustrated in 10c. the intramolecular aldol cyclization occurs to provide the desired product in $60 \%$ y ield. Overall. compared to the hydrogenative aldol reaction. the silane-mediated aldol reaction exhibited a lower chemical yield despite the prolonged reaction time.

We previously reported the results of the reductive Michael reaction in the presence of electronically different phsophines and the bidentate phosphine (Table 4). Under hydrogenation conditions using $5 \mathrm{~mol} \%$ of $\mathrm{P}\left(\mathrm{C}_{6} \mathrm{~F}_{5}\right)_{3} . \mathrm{P}\left(p-\mathrm{CF}_{3} \mathrm{C}_{6} \mathrm{H}_{4}\right)_{3} . \mathrm{PPh}_{3}$. and $\mathrm{P}\left(p-\mathrm{OMeC}_{6} \mathrm{H}_{4}\right)_{3}$, the reductive cyclizations of (2E.7E)1.9-diphenylnona-2.7-diene-1.9-dione 11a were previously presented (Table 4 , entries 1-4). ${ }^{12}$ Subsequently, electronically and sterically different phosphine ligands were tested in an attempt to improve the diastereoselectivity and chemical yield. The Pt complex with $\mathrm{P}\left(2,4.6-(\mathrm{OMe})_{3} \mathrm{C}_{6} \mathrm{H}_{2}\right)_{3}$ provided the product in $79 \%$ yield as a mixture of the syn and anti products (sw: anti $=35: 65$ ) (Table 4, entry 5). The Pt catalyst involving $\mathrm{P}(\text { fury })_{3}$ exhibited good activity comparable to that of $\mathrm{P}\left(p-\mathrm{CF}_{3} \mathrm{C}_{6} \mathrm{H}_{4}\right)_{3}$ but low diastereoselectivity (Table 4 . entry 6). The activity of the bidentate phospline ligand (dppe) was inferior to that of the monodentate phosphines (Table 4. entry 7). Throughout the optimization of the phosphine ligands. reasonable yields were obtained using the Pt catalysts involving $\mathrm{P}\left(p-\mathrm{CF}_{3} \mathrm{C}_{6} \mathrm{H}_{4}\right)_{3} . \mathrm{PPh}_{3}$ and $\mathrm{P}(\text { furyl })_{3}$. Subsequently, to improve the diastereoselectivity. a range of solvents (dichloromethane, acetone diethyl ether. $\mathrm{CH}_{3} \mathrm{CN}$. THF, and benzene) were applied. Under the conditions involving those solvents. desired reductive cyclization products were observed in modest to good yields. but the diastereoselectivity was not increased.

Next. reductive Michael reactions were conducted using $\mathrm{Et}_{3} \mathrm{SiH}$ as a reductant. The optimal catalyst for the hydrogenative Michael cyclization was applied. Using $\mathrm{PtCl}_{2}$ (5 $\mathrm{mol} \%), \mathrm{P}\left(p-\mathrm{CF}_{2} \mathrm{C}_{6} \mathrm{H}_{4}\right)_{3}\left(5 \mathrm{~mol}^{\%}\right), \mathrm{SnCl}_{2}(25 \mathrm{~mol} \%)$. and $\mathrm{Et}_{3} \mathrm{SiH}$ ( $150 \mathrm{~mol} \%$ ), conpound 11a was converted to $11 \mathrm{~b}$ in $71 \%$ yield as a mixture of the syn and anti isomers (sm: anti $=$ 29:71) (Table 4, entry 8). Sinular to the hydrogenative Michael reaction. in the absence of $\mathrm{SnCl}_{2}$, the catalytic activity of the Pt complex significantly decreases to provide the cyclization product in $24 \%$ yield (Table 4 . entry 9 ). In the presence of the electron-rich phosphine $\mathrm{P}\left(p-\mathrm{OMeC}_{6} \mathrm{H}_{4}\right)_{3}$, product 11b was formed in $52 \%$ yield (Table 4 . entry 10 ). Throughout the screening of the phosphine ligands. the combination of $\mathrm{PtCl}_{2}$. $\mathrm{P}\left(p-\mathrm{CF}_{3} \mathrm{C}_{6} \mathrm{H}_{4}\right)_{5}$, and $\mathrm{SnCl}_{2}$ was chosen for the reductive Michael cyclization of the bis-enones.

To explore the scope of the substrates. a variety of bisenones were evaluated under the standard reductive cyclization conditions involving $5 \mathrm{~mol} \%$ of $\mathrm{PtCl}_{2}, 25 \mathrm{~mol} \%$ of $\mathrm{SnCl}_{2} .5 \mathrm{~mol} \%$ of $\mathrm{P}\left(p-\mathrm{CF}_{3} \mathrm{C}_{6} \mathrm{H}_{4}\right)_{3}$, and $150 \mathrm{~mol} \%$ of $\mathrm{Et}_{3} \mathrm{SiH}$ (Table 5). Compared to the hydrogenative Michael cyclizations forming $11 \mathrm{~b}-1+\mathrm{c}^{12}$, with the silane as a reductant the catalytic activity appears to be lower. The reductive cyclization of 12a provided the 5 -membered ring $12 \mathrm{~b}$ in $57 \%$ yield with a mixture of the syn and anti products (sm:anti $=1: 1$ ). The electron-rich aromatic bis-enone 13a was converted to $\mathbf{1 3 b}$ in $89 \%$ yield with $1: 4$ ratio of the syn:anti products.

Table 5. Silane-mediated reductive Michael cyclization

Entry Yield (sminanij)


<smiles>C=CC(=O)c1ccccc1</smiles>

$1 a$<smiles>O=Cc1ccc([N+](=O)[O-])cc1</smiles>

$1 \mathbf{b}$

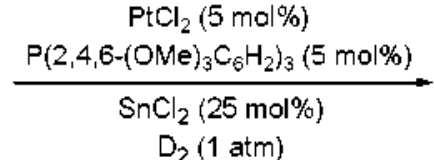

Dichloroethane $(0.1 \mathrm{M})$

$(200 \mathrm{mo} / \%)$ $(100 \mathrm{~mol} \%)$<smiles>O=C(/C=C/P)c1ccccc1</smiles>

$2 \mathbf{a}$<smiles>O=Cc1ccc([N+](=O)[O-])cc1</smiles>

$1 b$

$$
\begin{gathered}
\mathrm{PtCl}_{2}(5 \mathrm{mal} \%) \\
\stackrel{\mathrm{P}\left(2,4,6-(\mathrm{OMe})_{3} \mathrm{C}_{6} \mathrm{H}_{2}\right)_{3}(5 \mathrm{~mol} \%)}{\mathrm{SnCl}_{2}(25 \mathrm{mal} \%)} \\
\mathrm{D}_{2}(1 \mathrm{~atm})
\end{gathered}
$$

Dichloroethane $(0.1 \mathrm{M})$<smiles>[R]C([2H])([2H])C(C(=O)c1ccccc1)C(O)c1ccc([N+](=O)[O-])cc1</smiles>

deuterio-1c

$R=D(\sim 82 \%), H(\sim 18 \%)$<smiles>[R]C([2H])(c1ccccc1)C(C(=O)c1ccc([N+](=O)[O-])cc1)C(O)c1ccccc1</smiles>

deuterio-2c

$R=D(-71 \%), H(\sim 29 \%)$

Scheme 2. Deuterium labeling experiments<smiles>[X]CCCCC=CC(=O)c1ccccc1</smiles>

A
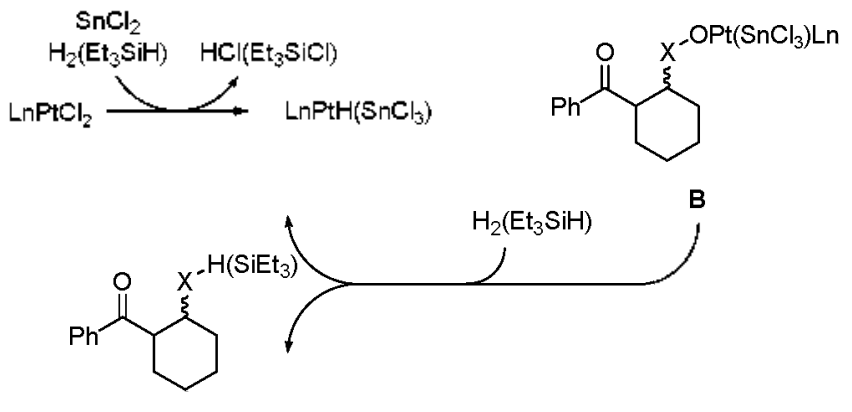

$\mathrm{X}=\mathrm{O}$ or $\mathrm{CHCOPh}$

Scheme 3. A proposed catalytic cycle

However, the unsy mmetrical bis-enones 14a exhibited much lower yields than the symmetric aromatic bis-enones. The symmetric aliphatic bis-enones and bis-enoates were not converted to the desired product.

With the aim of providing a better understanding of the platinum-catalyzed reductive coupling mechanism, deuterium labeling experiments were conducted. In $\mathrm{D}_{--m}$-mediated intermolecular aldol reaction the degree of deuterium incorporation at the $\beta$-position of the ketone was clearly determined by ${ }^{1} \mathrm{H}$ NMR. Deuterium labeling studies of the aldol reaction were conducted using phenylvinylketone $1 \mathrm{a}$ and chalcone $2 \mathrm{a}$ with $p$-nitrobenzaldehyde $\mathbf{1 b}$. Upon the exposure of compounds 1a and $1 \mathrm{~b}$ to the hydrogenation conditions using $\mathrm{D}_{2} .82 \%$ of the lydrogen at the methyl group of denterio-1c was exchanged with denterium. In the case of detterio-2c formed from chalcone 2 a. $71 \%$ of deuterium labeling was observed at the methylene. These results imply that the reversible hydrometalation of the platinum hydride to the enone occurs prior to the $\mathrm{C}-\mathrm{C}$ bond formation, affording a mixture of the deuterated and non-deuterated aldol products.

The catalytic cycle for the Pt-catalyzed reductive Michael reaction was previously proposed. ${ }^{12}$ Here. we propose a similar mechanism for the Pt-catalyzed reductive aldol reaction.
The catalytic cycle begins with the generation of $\mathrm{LnPtH}$ ( $\mathrm{SnCl}_{3}$ ) from $\mathrm{PtCl}_{2}$. phospluine, $\mathrm{SnCl}_{2}$. and $\mathrm{H}_{2}$ (or $\mathrm{Et}_{3} \mathrm{SiH}$ ). In Pt-catalyzed hydrogenation and hydroformylation. $\mathrm{SnCl}_{2}$ is known to function as a co-cataly st. ${ }^{4,5}$ Generally. the chloride of the Pt complex reacts with $\mathrm{SnCl}_{2}$ to afford $\mathrm{SnCl}_{3}{ }_{3}^{*}$. The role of the strong $\pi$-acceptor $\mathrm{SnCl}_{3}{ }^{-}$is speculated to promote the desired coupling and to prevent the reduction of Pt(II) complexes during the reaction. ${ }^{\text {sc }}$ Upon its exposure to the reaction mixture containing $\mathrm{LnPHH}\left(\mathrm{SnCl}_{3}\right)$. the enone undergoes hydrometalation to form intermediate $\mathbf{A}$. as indicated by the deuterium labeling results. The subsequent addition of the Pt-enolate $\mathbf{A}$ to the aldelyyde forms the internediated $\mathbf{B}$. Finally. the oxidative addition of hydrogen or the silane to the intermediate $\mathbf{B}$ and reductive elinination afford the product with the concomitant generation of $\mathrm{LnPtH}\left(\mathrm{SnCl}_{3}\right)$.

\section{Conclusion}

We have developed the catalytic nucleophilic addition of Pt-enolates to aldelyydes or enones in the presence of $\mathrm{H}_{z}$ or $\mathrm{Et}_{3} \mathrm{SiH}$. Using $\mathrm{PtCl}_{2}$ with phosphine ligands and reductants. various enones. aldelydes and bis-enones participated in this reaction to afford the corresponding products in good to modest yield. Noticeably, under reductive aldol reaction conditions. in most cases, electron-rich phsophines $\left(\mathrm{P}\left(p-\mathrm{OMeC}_{6} \mathrm{H}_{4}\right)_{3}\right.$ and $\left.\mathrm{P}\left(2.4 .6-(\mathrm{OMe})_{3} \mathrm{C}_{6} \mathrm{H}_{2}\right)_{3}\right)$ are favored as ligands. On the other hand, the reductive Michael reaction requires $\mathrm{P}\left(p-\mathrm{CF}_{\mathbf{5}}\right.$ $\left.\mathrm{C}_{6} \mathrm{H}_{4}\right)_{3}$ for good conversion. Accordingly: tuning the electronic properties of the $\mathrm{Pt}$ and phosphine complexes is vital for the good conversion of the reactions involving different substrates. In terms of the reactivity of the reductants. the hydrogenmediated aldol and Michael reactions exhibited significantly higher yields than the silane-mediated reactions. To understand the mechanism, deuterium labeling experiments were carried out using enones and aldelydes. supporting the formation of $\mathrm{LnPtH}$ and its subsequent hydrometalation to the enone. Our methodology involving Pt catalysts and reductants $\left(\mathrm{H}_{2}\right.$ and $\mathrm{Et}_{3} \mathrm{SiH}$ ) demonstrates the nucleophilic activity of Pt-enolates complexes to the electron-deficient functional groups, which is an exciting extension of the catalytic activity of Pt complexes in organic reactions. 


\section{Experimental Section}

General. All reactions were nun under an atmosphere of argon, unless otherwise indicated. Anhydrous solvents were transferred by an oven-dried sy ringe. Flasks were flame-dried and cooled under a stream of nitrogen. Dichloroethane was distilled from calcium hydride. Analytical thin-layer chromatography (TLC) was carried out using 0.2-mm commercial silica gel plates (DC-Fertigplatten Krieselgel $60 \mathrm{~F}_{3_{5}}$ ). Preparative column chromatograply employing silica gel was performed according to the method of Still. ${ }^{13}$ Solvents for chromatography are listed as volume/volume ratios. Proton nuclear magnetic resonance ( ${ }^{\mathrm{H}} \mathrm{NMR}$ ) spectra were recorded with a Mercury ( $400 \mathrm{MHz}$ ) spectrometer. Chemical Shifts are reported in delta ( $\delta$ ) units, parts per million (ppm) downfield from trimethylsilane. Coupling constants are reported in Hertz (Hz). Carbon-13 muclear magnetic resonance $\left({ }^{13} \mathrm{C}\right.$ NMR) spectra were recorded with a Mercury $400(100 \mathrm{MHz})$ spectrometer. Chemical shifts are reported in delta(ô) units. parts per million (ppm) relative to the center of the triplet at $77.00 \mathrm{ppm}$ for denteriochloroform. ${ }^{13} \mathrm{C}$ NMR spectra were routinely' nin with broadbrand decoupling. Product $1 \mathbf{c}^{1 /}{ }^{1} \mathbf{5}$. $^{\text {lla }}$ $9 c^{14}{ }^{10 c}{ }^{11 a} 11 b-14 c^{12}$ exhibited spectral properties consistent with previous literature reports. Spectral characterization of new compounds $2 c-4 c$ and $6 c-8 c$ are available in supplementary data.

Representative Experimental Procedure for HydrogenMediated Reductive Aldol Reaction To the premixed solution of $\mathrm{PtCl}_{2}(5 \mathrm{~mol} \%), \mathrm{P}\left(2.4,6-(\mathrm{OMe})_{3} \mathrm{C}_{6} \mathrm{H}_{3}\right)_{3}(10 \mathrm{~mol} \%)$, and $\mathrm{SnCl}_{2}(25 \mathrm{~mol} \%)$. in dichloroethane $(0.1 \mathrm{M})$ under $\mathrm{H}_{2}$ (latm) were added $200 \mathrm{~mol} \%$ of $1 \mathrm{a}$ and $100 \mathrm{~mol} \%$ of $1 \mathrm{~b}$ at room temperature. The resulting mixture was allowed to run at 80 ${ }^{\circ} \mathrm{C}$ for 2 hours. The solvent was removed with a rotary evaporator to produce a residue which was purified by column chromatography on a silica gel eluting with hexane and ethyl acetate.

Representative Experimental Procedure for TriethylsilaneMediated Reductive Aldol Reaction. To the premixed solution of $\mathrm{PtCl}_{2}(5 \mathrm{~mol} \%), \mathrm{P}\left(p-\mathrm{OMeC}_{6} \mathrm{H}_{4}\right)_{3}(5 \mathrm{~mol} \%), \mathrm{SnCl}_{2}(25$ $\mathrm{mol} \%)$. and $\mathrm{Et}_{3} \mathrm{SiH}(150 \mathrm{~mol} \%)$ in dichloroethane $(0.1 \mathrm{M})$ were added $200 \mathrm{~mol} \%$ of $1 \mathrm{a}$ and $100 \mathrm{~mol} \%$ of $1 \mathrm{~b}$ at room temperature. The resulting mixture was allowed to run at 50 ${ }^{\circ} \mathrm{C}$ for 24 hours. The solvent was removed with a rotary evaporator to produce a residue which was purified by column chromatography' on a silica gel eluting with hexane and ethỵl acetate

Representative Experimental Procedure for HydrogenMediated Reductive Michael Cyclization. To the premixed solution of $\mathrm{PtCl}_{2}(5 \mathrm{~mol} \%), \mathrm{P}\left(p-\mathrm{CF}_{3} \mathrm{C}_{6} \mathrm{H}_{4}\right)_{3}(5 \mathrm{~mol} \%)$. and $\mathrm{SnCl}_{2}(25 \mathrm{~mol} \%)$, in dichloroethane $(0.1 \mathrm{M})$ under $\mathrm{H}_{z}$ (latm) were added $100 \mathrm{~mol} \%$ of $11 \mathrm{a}$ at room temperature. The resulting mixture was allowed to run at $80^{\circ} \mathrm{C}$ for 2 hours. The solvent was removed with a rotary evaporator to produce a residue which was purified by column chromatography on a silica gel eluting with hexane and ethyl acetate.

Representative Experimental Procedure for TriethylsilaneMediated Reductive Aldol Reaction. To the premixed solution of $\mathrm{PtCl}_{2}(5 \mathrm{~mol} \%) . \mathrm{P}\left(p-\mathrm{CF}_{3} \mathrm{C}_{6} \mathrm{H}_{4}\right)_{3}(5 \mathrm{~mol} \%) . \mathrm{SnCl}_{2}(25 \mathrm{~mol} \%)$. and $\mathrm{Et}_{3} \mathrm{SiH}(150 \mathrm{~mol} \%)$ in dichloroethane $(0.1 \mathrm{M})$ were added $100 \mathrm{~mol} \%$ of 11a at room temperature. The resulting mixture was allowed to run at $50{ }^{\circ} \mathrm{C}$ for $2+$ hours. The solvent was removed with a rotary evaporator to produce a residue which was purified by column chromatography on a silica gel eluting with hexane and etlyy acetate.

Aclonowledgments. This work was supported by the Korea Science and Engineering Foundation (grant No. R01-2007000-20223-0) and the Korea Research Foundation (grant No. KRF-2007-412-J04003).

Supporting Information. Experimental procedures and spectral characterization of compounds $2 \mathrm{c}-\mathbf{4 c}$ and $\mathbf{6 c - 8 c}$ are available at the bkcs website (http rwww kcsnet.or.kr:bkcs).

\section{Refeiences}

1. (a) Zhang, L.; Sun, T; Kozmin, S. A. Adw. Syth Catol. 2006, 348, 2271. (b) Liu, C.; Bender, C. F.; Han, X.; Widenhoefer, R. A. Chem. Commun 2007, 3607. (c) Michelet, V.; Toullec, P. Y; Genêt J.-P. Angew. Chem. Int Ed. 2008, 17,4268 .

2. (a) Tiang, X.-b.; Minnaard, A. J ; Feringa, B. L.; de Vries, T. G. $J$. Org. Chent 2004, 69, 2327. (b) Wang, X.; Widenhoefer, R. A. Organontetallics 2004, 23, 1649 . (c) Liu, C.; Han, X; Wang, X: Widenhoefer, R. A. J.Am. Chem. Soc. 2004, 126, 3700 (d) Qian, H.: Han, X.: Widenhoefer, R. A. J. Am. Chem. Soc. 2004, 126, 9536. (e) Bender, C. F.: Widenhoefer, R. A. J. Am. Chem. Soc. 2005, 127, 1070. (f) Bigeault, I.; Giordano, L.: de Riggi, I.; Gimbert, Y.: Buono, G. Org. Letr. 2007, 9, 3567.

3. (a) Chalk, A. I.: Harrod, I. F. J. Am Chem Soc. 1965, 87, 16 (b) Delpech, F.; Asgatay, S.: Castel, A.: Rivière, P.; Rivière-Bandet, M.: Amin-Alami, A.: Manriquez, J. Appl. Organomet. Chem. 2001, 15,626. (c) Itazaki, M; Nishihara, Y; Osakada, K. J. Org. Chem 2002, 67, 6889. (d) Sprengers, T. W.; Mars, M. T.; Duin, M. A.; Cavell, K. T.; Elsevier, C. T. J. Organomet. Chem. 2003, 679, 149. (e) Belr, A.; Naendrup, F.; Obst, D. Adv. Shnth. Catal. 2002, 34t, 1 142. (f) Buisine, O.; Berthon-Gelloz, G.; Brière, J.-F.; Stérin, S.; Mignani, G.; Branlard, P.; Tinant, B.; Declercq. J.-P.; Markó, I. E. Chemt. Conmun 2005, 3856. (g) De Bo, G.; Berthon-Gelloz, G.; Tinant, B.; Markó, I. E. Organontetallics 2006, 25, 1881. (h) Diez-González, S.; Blanco, L. J. Organomet. Chem. 2008, 693, 2033 .

4. (a) Cramer, R. D.; Lindsey, Ir. R. V.; Prewitt, C. T.; Stolberg, U. G. J. Am. Chem Soc 1965, 87,658 (b) Cramer, R.: Linsey, Ir. R. V. J. Am. Chem. Soc $1966,88,3534$. (c) Clark, H. C.: Tsang, W. S. J. Am. Chem. Soc 1967, 89,529. (d) Clark, H. C.: Dixon, K. R.: Jacobs, W. I. J. Am Chem. Soc. 1969, 91, 1346. (e) Clark, H. C.: Kurosawa, H. Inorg. Chem 1972, 11, 1275. (f) Clark, H. C.; Kurosawa, H. horg. Chem. 1973, 12, 357. (g) Clark, H. C. Kurosawa, H. Inorg. Chent. 1973, 12, 1566. (h) Clark, H. C.; Jablonski, C. R.; Wong, C. S. Inorg. Chent. 1975, 14, 1332. (i) Kurosawa, H. horg. Chent. 1976, 15, 120. (j) Gómez, M.; Muller, G.; Salız, D.; Sales, T. Organometallics 1991, 10, 4036.

5. (a) Hsu, C.-Y.; Orchin, M. J. Am. Chem. Soc. 1975, 97, 3553. (b) Pittman, Ir. C. U.; Kawabata, Y.; Flowers, L. I. J. Chem. Soc., Chen. Commun. 1982, 473. (c) Holt, M. S.; Wilson, W. L.; Nelson, J. H. Chem. Rev. 1989, 89, 11 (d) Stille, J. K.: Su, H.; Brechot, P.; Parrinello, G.; Hegedus, L. S. Organometallics $1991,10,1183$

6. (a) Madine, I. W.: Wang, X.: Widenhoefer, R. A. Org. Lett. 2001, 3, 385. (b) Wang. X.; Chakrapani, H.: Madine, I. W.; Keyerleber, M. A.: Widenhoefer, R. A. J. Org. Chem 2002, 67. 2778. (c) Jung, I. G.; Seo, T.; Lee, S. I.; Choi, S. Y.: Chung, Y. K. Organometallics 2006, 25, 4240 . 
7. (a) Arisawa, M.; Terada, Y.: Takahashi, K: Nakagawa, M.: Nishida, A. J. Org Chem 2006, 71, 4255. (b) Ikeda, S.-i.: Daimon, N.; Sanuki, R: Odashima, K. Chem. Eur. J. 2006, 12, 1797.

8. (a) Ojima, I: Tzamarioudaki, M.: Li, Z: Donovan, R. T. Chent. Rev. 1996, 96, 635. (b) Auber, C.; Buisine, O.; Malacria, M. Chem. Rev 2002, 102, 813. (c) Molander, G. A.; Romero, A. C. Chem. Rev 2002,102,2161. (d) Widenhoefer, R. A. Acc. Chem. Res. 2002, 35, 905 (e) Ikeda, S.-I. Angew. Chent. Int. Ed. 2003, 42,5120. (f) Huddleston, R. R.; Krische, M. T. Sylnett 2003, 12. (g) Montgomery, J. Angew. Chem. Iht. Ed. 2004, 13, 3890 (h) Krische, M. I., Tang, H.-Y. In Comprehensive Organometallic Chemistry HI, Crabtree, R. H., Mungos, D. M. P., Eds.: Elsevier: Oxford, 2007; Vol 10, p 493. (i) Widenhoefer, R. A.; Bender, C. $\mathrm{F}$. In Comprehensive Organontallic Chemistry $\mathrm{HI}$; Crabtree, $\mathrm{R}$. H., Mingos, D. M. P., Eds.; Elsevier: Oxford, 2007; Vol 1l, p 367. (i) Shucas, E.; Ngai, M.-Y.: Konnanduri, V.; Krische, M. I. Acc. Chent. Res. 2007, t0, 1394.

9. Nelson, S. G. Tetrahe dron Astmmetry 1998, 9, 357

10. (a) Revis, A.: Hilty, T. K. Tetrahetron Lett. 1987, 28, 4809. (b) Matsuda, I.: Takahashi, K.: Sato, S. Tetrahedron Lett. 1990, 31, 5334. (c) Taylor, S. T.; Morken, I. P. J. Am. Chem. Soc, 1999 , 121,12202 . (d) Zhao, C. X.: Duffey, M. O.; Tavlor, S. J.: Morken, I. P. Org. Lett. 2001, 3, 1829. (e) Zhao, C.-X.; Bass, I.; Morken. J. P. Org. Lett. 2001, 3. 2839 (f) Baik. T.-G.: Luis, A. L.: Wang, L.-C.; Krische, M. I. J. Am. Chem. Soc. 2001, 123, 5112. (g) Wang, L.-C.; Jang, H.-Y; Roh, Y.; Lvnch, V.; Schultz,
A. J.; Wang, X.; Krische, M. J. J. Am. Chent Soc. 2002, 124, 9448. (h) Shibata, I.; Kato, H.: Ishida, T.: Yasuda, M.; Baba, A. Angew. Chem. Int. Ed. 2004, 43, 7l l. (i) Miura, K.; Yamada, Y.; Tomita, M.: Hosomi, A. Synlett 2004, 1985 . (j) Freiria, M.; Whitehead, A. . .; Tocher, D. A.; Motherwell, W. B. Tetrhedron 2004, 60, 2673. (k) Nishiyama, H.; Shiomi, T.; Tsuchiya, Y: Matsuda, I. J. Am. Chem. Soc 2005, 127,6972 (1) Shiomi, T:; Ito, J.-I: Yamamoto, Y: Nishivama, H. Eur. J. Org. Chem. 2006, 5594. (m) Zhao, G.-L.: Cordova, A. Tetrahedron Lett. 2006, 77, 7417, (n) Lumby, R. J. R; Toensuu, P. M.; Lam, H. W. Org. Left 2007, 9, 4367. (o) Chrovian, C. C.; Montgomery, I. Org. Lett. 2007, 9, 537. (p) Nishiyama, H.; Shiomi, T. Top Cun: Chent 2007, 279, 105 .

11. (a) Jang, H. -Y.; Huddleston, R. R.: Krische, M. I. J. Am. Chem. Soc. 2002, 124, 15156. (b) Jang, H.-Y.; Krische, M. J. Acc. Chem Res. 2004, 37, 653. (c) Jang, H.-Y, Krische, M. J. Eur. J. Org. Chem 2004, 19, 3953. (d) Jung. C. K.: Krische, M. I. J. Am. Chemt. Soc. 2006, 128, 17051 . (e) Gamer, S. A.; Krische, M. T. J. Org. Chem 2007, 72, 5843. (f) Bee, C.; Han, S. B.: Hassan, A.; Iida. H.: Krische, M. J. J. Am. Chem. Soc. 2008, 130, 2746.

12. Lee, H.; Jang, M.-S.; Hong, J.-T.; Tang, H.-Y. Tetrohedron Lett. $2008,+9,5785$

13. Still, W. C.: Kahn, M.; Mitra, A. J. Org. Chemt 1978, 43, 2923.

14. Arime, T.: Kato, N.; Komadate, F ; Saggusa, H.: Mori, N. Synth. Conmm 1994, 24, 3315 . 